\title{
PENGELOLAAN ZAKAT PRODUKTIF DALAM PENGENTASAN KEMISKINAN DI KABUPATEN BANYUMAS
}

\author{
Septi Wahyuningsih ${ }^{1}$, Makhrus $^{2}$ \\ ${ }^{1}$ Universitas Muhammadiyah Purwokerto, Email : s3pti.wahyu@gmail.com \\ 2Universitas Muhammadiyah Purwokerto, Email : makhrus.ahmadi@gmail.com
}

\begin{abstract}
ABSTRAK
Kemiskinan menjadi permasalahan utama dalam perkembangan sebuah Negara. Penduduk Kabupaten Banyumas mayoritas beragama islam, zakat merupakan salah satu instrument dalam islam yang memiliki peranan penting dalam pengentasan kemiskinan jika terkelola dengan baik. Tujuan penelitian ini untuk mengetahui pengelolaan dan program zakat produktif dalam pengentasan kemiskinan yang dilakukan oleh organisasi pengelola zakat Kabupaten Banyumas. Penelitian ini menggunakan jenis penelitian kualitatif deskriptif dengan teknik pengumpulan data yaitu wawancara, observasi, dan dokumentasi. Metode analisis menggunakan data primer berupa data laporan tahunan BAZNAS dan LAZISMU Kabupaten Banyumas serta menggunakan teori pendekatan (CIBEST) Center for Islamic Business and Economic Studies dengan analisis data mensinkronsasikan data penelitian dengan teori sebagai penunjang yang menghasilkan sebuah simpulan. Hasil penelitian ini menunjukan bahwa pengelolaan zakat yang dilakukan oleh organisasi pengelola zakat Kabupaten Banyumas sebagian besar digunakan untuk kegiatan konsumtif yang ditunjukkan dengan $60 \%$ untuk konsumtif dan $40 \%$ untuk produktif. Sementara pengelolaan zakat produktif dalam pengentasan kemiskinan di Kabupaten Banyumas meliputi bantuan modal usaha, bantuan sarana prasarana, bantuan ternak, usaha binaan, kantin sehat, pelatihan skill, beasiswa pendidikan, dan pemberdayaan usaha kecil menengah. Program yang dilakukan kedua organisasi tersebut bersifat charity dan pemberdayaan. Program zakat produktif yang dilakukan oleh organisasi pengelola zakat di Kabupaten Banyumas dalam pengentasan kemiskinan dilakukan dengan pemberdayaan masyarakat. Berdasarkan pendekatan CIBEST menunjukan bahwa program pemberdayaan terdapat peningkatan jumlah pendapatan usaha, stimulant, kesadaran spiritual, dan perubahan paradigma pada mustahik. Hambatan yang dihadapi organisasi pengelola zakat di Kabupaten Banyumas dalam pengentasan kemiskinan yakni kurangnya koordinasi dengan mitra program pemberdayaan, lemahnya pengawasan, kurangya sumber daya manusia, dan evaluasi
\end{abstract}

Kata-kata kunci : Pengelolaan, Zakat Produktif, Kemiskinan

\section{ABSTRACT}

Poverty is a major problem in the development of a country. The majority of residents in Banyumas Regency are Muslim, zakat is one of the instruments in Islam which has an important role in 
alleviating poverty if managed properly. The purpose of this study was to determine the management and productive zakat program in poverty alleviation carried out by the zakat management organization Banyumas Regency. This research uses descriptive qualitative research with data collection techniques, namely interviews, observation, and documentation. The method of analysis uses primary data in the form of annual BAZNAS and LAZISMU report data in Banyumas Regency and uses the theory of approach (CIBEST) Center for Islamic Business and Economic Studies by analyzing data synchronizing research data with theories as support that produce a conclusion. The results of this study indicate that the management of zakat carried out by zakat management organizations in Banyumas Regency is mostly used for consumptive activities as indicated by $60 \%$ for consumptive and $40 \%$ for productive activities. While the management of productive zakat in poverty alleviation in Banyumas Regency includes business capital assistance, infrastructure assistance, livestock assistance, built businesses, healthy canteens, skill training, educational scholarships, and empowerment of small and medium enterprises. The programs carried out by the two organizations are charity and empowerment. The productive zakat program carried out by zakat management organizations in Banyumas District in poverty alleviation is done by community empowerment. Based on the CIBEST approach, it shows that empowerment programs have an increase in the amount of business income, stimulation of spiritual awareness, and paradigm shift in mustahik. Obstacles faced by zakat management organizations in Banyumas District in alleviating poverty are lack of coordination with partner empowerment programs, weak supervision, lack of human resources, and evaluation.

Keywords: Management, Productive Zakat, Poverty

\section{PENDAHULUAN}

Kemiskinan masih menjadi permasalahan utama di banyak negara berkembang termasuk Indonesia. Angka kemiskinan di Indonesia kini mencapai angka $14 \%$ dari jumlah total penduduk. Oleh sbeb itu, berbagai usaha di tempuh, termasuk perusahaan-perusahaan di lingkungan masyarakat belum memberikan sebuah peran dalam mengatasi pengganguran sebagai salah satu penyebab kemiskinan, pengelolaan Corporate Social Responsibility (CSR) yang ada dalam program perusahaan tersebut sebatas pendekatan struktural kepentingan antara pihak perusahaan dan masyarakat. Program pemberian dana dari beberapa komunitas atau suatu lembaga hanya bersifat sementara tidak berkesinambungan.

Keberhasilan Kabupaten Banyumas dalam menanggulangi kemiskinan belum sepenuhnya berhasil. Menurut Badan Pusat Statistik Daerah Banyumas, tergambar dari jumlah penduduk miskin yang masih tinggi pada tahun 2016 yaitu 283,5 jiwa dari jumlah 2.021.004 penduduk. 
Penurunan angka kemiskinan dari tahun ke tahun, tidak pernah mencapai angka 1 persen. Pada 2015 angka kemiskinan di Banyumas mencapai 17,52 persen, maka pada 2016 hanya turun menjadi 17,23 persen. Sehingga saat ini angka kemiskinan di Banyumas masih masuk ke jajaran kabupaten tertinggi di Provinsi Jateng terkait jumlah penduduk miskin. Dalam hal ini, Kabupaten Banyumas menduduki ranking ke-28 dari 35 kabupaten/kota dalam hal jumlah penduduk miskin. Perkembangan perkotaan serta kemajuan akan transportasi dan fasililtas lain menimbulkan sisi positif dan negatif, namun taraf kemiskinan masih terus menjadi sebuah permasalahan yang ada. Kabupaten Banyumas merupakan daerah yang memiliki potensi dana zakat yang cukup tinggi. Data Badan Pusat Statistik tahun 2015 menyatakan bahwa jumlah penduduk Kabupaten Banyumas mencapai 2 juta jiwa dan 1,7 juta jiwa pemeluk agama Islam atau sekitar $88 \%$ dari seluruh pemeluk agama yang ada di Kabupaten Banyumas. Hanya saja permasalahan yang muncul adalah pengelolaan dan pengumpulan dana zakat tidak dilakukan secara sistematis dan terstruktur sehingga kemanfaatan dana zakat yang besar tersebut tidak maksimal.

Pendistribusian dana ZIS terutama zakat kini telah berkembang, dari awalnya hanya berorientasi pada pemenuhan kebutuhan konsumtif saat ini sudah mencapai pada zakat sebagai sumber dana produktif yang dapat mendongkrak perekonomian lebih jauh lagi. Akan tetapi, sebagian masyarakat masih belum paham mengenai pendsitribusian dana zakat untuk kegiatan produktif. Oleh karena sebab itu, peran dana zakat untuk mengentaskan kemiskinan pada ekonomi mustahik masih kurang dirasakan. Karena kebanyakan masyarakat masih mendistribusikan dana zakatnya hanya untuk tujuan konsumtif saja. Sehingga dengan adanya zakat produktif diharapkan terjadi perubahan dari seseorang yang awalnya seorang mustahik menjadi seorang muzakki. Di Indonesia sendiri, zakat produktif telah disahkan oleh MUI pada tahun 1982 (Wulansari, 2013: 7).

Undang-undang No. 23 tahun 2011 tentang pengelolaan zakat menyatakan bahwa lembaga pengelolaan zakat di Indonesia terdiri atas dua kelompok institusi, yaitu Badan Amil Zakat (BAZ) dan Lembaga Amil Zakat (LAZ). BAZ dibentuk pemerintah, sedangkan LAZ dibentuk oleh masyarakat. Undangan-Undang tersebut menjawab keraguan masyarakat atas pengelolaan zakat. Sehingga masyarakat diharapakan dapat menyalurkan zakatnya melalui lembaga terpercaya dalam naungan 
perundang-undangan dan adanya kejelasan dalam sistem pelaporannya. Perlu adanya sosialisasi dan komunikasi intensif kepada semua lapisan masyarakat terutama para amil yang terbentuk di masjid-masjid untuk dapat ikut serta dalam berkontribusi dengan adanya peran BAZ dan LAZ.

Penelitian serupa telah dilakukan oleh beberapa peneliti di antaranya dilakukan oleh Hani Widyani (2014) bahwa program dana bergulir digunakan sebagai modal usaha mustahik dalam pengentasan kemiskinan. Makhrus dan Restu Frida Utami (2014) bahwa lembaga filantropi Islam di Kabupaten Banyumas dalam melakukan pemberdayaan masyarakat melalui dua kegiatan yaitu charity dan pemberdayaan yang sudah terencana tersusun secara tertata. Penelitian selanjutnya dilakukan oleh Nasrullah (2015) bahwa zakat produktif yang diberikan kepada mustahik untuk menunjang kegiatan usaha menggunakan pola Qard (pinjaman tanpa bunga), pinjaman zakat produktif ini signifikan terhadap kemandirian masyarakat dalam mengatur ekonominya sendiri. Artinya, pengelolaan zakat produktif secara umum didistribusikan dalam beberapa sektor seperti, pendidikan, ekonomi, dakwah, kesehatan, dan sosial keagamaan. Sedangkan untuk pengukur efektifitas pelaksanaan program dan bentuk evaluasi program, organisasi pengelola zakat memiliki metode tersendiri, meski secara keseluruhan menunjukkan respon positif, mulai dari partipasi masyarakat, dukungan pemerintah, dan profesionalitas kelembagaan lembaga zakat (Makhrus, 2019: 49)

\section{METODE PENELITIAN}

Penelitian ini menggunakan pendekatan kualitatif. Data yang dikumpulkan bersumber dari naskah wawancara, catatan lapangan, dan dokumentasi resmi lainnya. Sehingga yang menjadi tujuan dari penelitian ini adalah ingin menggambarkan realita empirik di balik fenomena secara mendalam, rinci, dan tuntas. Oleh karena itu pendekatan kualitatif dalam penelitian ini adalah dengan mencocokan realita empirik dengan teori yang berlaku dengan menggunakan metode deskriptif (Herdiansyah, 2011: 8). Metode pengumpulan data yang digunakan adalah metode wawancara, dan dokumentasi. Jenis wawancara yang dipilih adalah deep interview (wawancara mendalam). Data utama diperoleh dari informan peneliti, dalam hal ini Direktur LAZISMU Banyumas dan BAZNAS Kabupaten Banyumas. Sedangkan data tambahan diambil dari dokumen LAZISMU 
dan BAZNAS Kabupaten Banyumas. Analisis data yang digunakan adalah analisis data kualitatif model mile dan Humberman yang terkenal dengan analisis interaktif yang meliputi tiga hal yaitu: mereduksi data, menyajikan data ke dalam bentuk teks naratif dan penarikan kesimpulan.

\section{HASIL DAN PEMBAHASAN}

Pengelolaan adalah penyelenggaraan, pengurus, atau proses yang membantu merumuskan kebijakan dan tujuan organisasi. Pengelolaa sama halnya dengan manajemen. Menurut James A. F. Stoner bahwa manajemen adalah perencanaan, pengeorganisasian, pengarahan, dan pengawasan usaha-usaha para anggota organisasi lainnya agar dapat mencapai tujuan organisasi yang diterapkan (Mujahidin, 2016: 34). Menurut Undang-undang No 23 tahun 2011 tentang pengelolaan zakat badan amil zakat ataupun lembaga zakat lainnya harus mampu menyelenggarakan fungsi-fungsinya sebagai berikut yaitu: pertama, perencanaa pengumpulan, pendistribusian, dan pendayagunaan zakat. Kedua, pelaksanaan pengumpulan, pendistribusian, dan pendaayagunaan zakat. Ketiga, pengendalian pengumpulan, pendistribusian, dan pendayagunaan zakat. Keempat, pelaporan pengumpulan, pendistribusian, dan pendayagunaan zakat. Secara bahasa zakat merupakan kata dasar dari zaka yang berarti suci, berkah, tumbuh, dan terpuji. Zakat dari istilah fikih berarti sejumlah harta tertentu yang diwajibkan Allah untuk diserahkan kepada orang-orang yang berhak (Sudarsono, 2003: 265). Menurut etimologi yang dimaksudkan dengan zakat adalah sejumlah harta tertentu yang telah mencapai syarat tertntu yang diwajibkan Allah untuk dikeluarkan dan diberikan kepada orang-orang yang berhak menerimanya. Adapun 8 (delapan) golongan orang-orang yang berhak menerima zakat yaitu seperti yang tersebut di dalam Al-qur'an Surah At-Taubah ayat 60 :

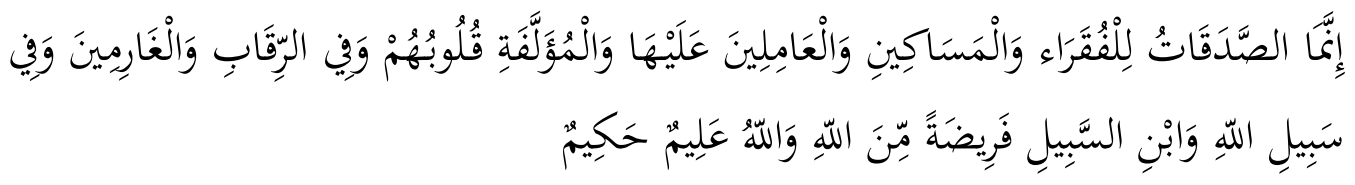

"Sesungguhnya zakat-zakat itu, hanyalah untuk orang-orang fakir, orang-orang miskin, pengurus-pengurus zakat, Para mu'allaf yang dibujuk hatinya, untuk (memerdekakan) budak, orang-orang yang berhutang untuk jalan Allah dan untuk mereka yang sedang dalam perjalanan, sebagai suatu ketetapan yang diwajibkan Allah, dan Allah Maha mengetahui lagi Maha 
Bijaksana."

Beberapa syarat wajib dan syarat sah seorang muslim untuk membayarkan zakatnya diantaranya yakni: seorang muslim yang telah baligh, yang memiliki akal sehat, merdeka, bebas dari hutang, yang memiliki kekayaan penuh yang telah mencapai nisab dan haul serta merupakan barang yang berkembang (Triyawan dkk, 2017: 60). Secara umum kewajban zakat ini ada dua jenis, yakni: pertama, zakat maal atau zakat harta yaitu zakat yang di kenakan atas harta tertentu setelah memenuhi persyaratan tertentu, yaitu persyaratan pemenuhan waktu (haul) dan persyaratan jumlah (nisab). Sebagai implikasinya adanya perbedaan harta maka bisa berbeda pula batas waktu kapan zakat harus dibayarkan dan berapa jumlah minimal harta yang harus dibayarkan zakatnya. Kedua, zakat fitrah yaitu zakat yang wajib dikeluarkan umat islam, baik laki-laki, perempuan, besar kecil, merdeka atau budak, tua, dan muda pada awal bulan Ramadhan sampai menjelang Idul Fitri (Muljawan dkk ,2016: 61).

Zakat produktif adalah harta zakat yang disalurkan kepada orang-orang yang berhak dan dapat diberdayakan. Karena hakikat zakat bukanlah berapa rupiah yang diterima oleh para penerima zakat (mustahik), namun bagaimana zakat tersebut bisa meningkatkan kesejahteraan umat. Selain itu zakat produktif merupakan sumber dana potensial yang dapat dimanfaatkan untuk memajukan kesejahteraan umum bagi seluruh masyarakat yang digunakan sebagai modal untuk menjalankan suatu kegiatan ekonomi yaitu untuk menumbuh kembangkan tingkat ekonomi, dan potensi produktifitas mustahik (Nasrullah, 2015: 6). Pendayagunaan zakat produktif diatur dalam pasal 27 Undang-Undang No. 23 Tahun 2011 tentang pengelolaan zakat yaitu, zakat dapat didayagunakan untuk usaha produktif dalam rangka penanganan fakir miskian dan peningkatan kualitas umat, Pendayagunaan zakat untuk usaha produktif sebagaimana dimaksud pada ayat (1) dilakukan apabila kebutuhan mustahik telah terpenuhi.

Istilah pengentasan dalam Kamus Besar Bahasa Indonesia 
mempunyai arti proses, cara, perbuataan, sehingga dapat disimpulkan bahwa pengentasan adalah suatau upaya yang bersifat nyata melalui adanya suatu gerakan sehingga menimbulkan suatu dampak nyata dari upaya tersebut. Upaya pengentasan ini diharapakan tidak hanya sekedar mengurangi jumlah kemiskinan namun perlu adanya upaya pembangunan. Pembangunan dimaknai adanya perbaikan terhadap orang, bukan hanya pendapatannya namun lebih umum pada adanya perubahan pilihan, kemampuan dan kebebasan mereka serta perubahan distribusi kesempatan perbaikan. Sedangkan secara etimologi pembangunan dalam perspektif Islam yaitu peningkatan kesadaran insan atau tanggungjawab terhadap berbagai hakikat dan masalah mengikuti urutan keutamaan yang sah, dan amal perbuatan yang ikhlas, berhikmah, berani, sederhana, dan adil (Syamsuri, 2016: 225). Analisis tentang kemiskinan bergantung pada sudut pandang yang diambil. Sehingga Definisi kemiskinan dan kriteria kemiskinan bisa bersifat subyektif maupun obyektif. Menurut the Statistical Economic and Social Research and Training Center for Islamic countris (SESRIC) pada tahun 2015 yang dikutip oleh Bank Indonesia menjelaskan bahwa kemiskinan dibagi menjadi dua yaitu; kemiskinan relatif dan kemiskinan absolut. Kemiskinan relatif yaitu kemiskinan yang diukur sebagai persentase penduduk dengan pendapatan dibawah nilai median pendapatan, yang membandingkan antara kelompok terendah dan kelompok di atasnya. Kemiskinan Absolut yaitu kemiskinan yang mencerminkan pendapatan layak minimum individual untuk memenuhi kebutuhan pokok untuk bisa bertahan hidup (Muljawan dkk, 2016: 7).

Menurut Irfan Syauqi Beik \& Laily Dwi Arsyianti dalam melihat suatu garis kemiskinan tidak hanya dilihat dari masalah materiil saja namun aspek spiritual masuk dalam hal tersebut. Dalam penemuanya beik menjelaskan bahwa ada empat kuadran yang dapat menjadi bahan evalusi upaya pengentasan kemiskinan atau lebih sering kita kenal dengan model CIBEST (Center for Islamic Business 
and Economic Studies). Dalam model CIBEST Beik dan Arsyianti membagi konsidi suatu rumah tangga atau keluarga ke dalam empat kelompok (quadran). Pertama; suatu rumah tangga memiliki kemampuan dalam memenuhi kebutuhan spiritual dan material disebut dengan rumah tangga sejahtera. Kedua; suatu rumah tangga hanya mampu memenuhi kebutuhan spiritual saja disebut dengan konsidi kemiskinan material. Ketiga; Suatu rumah tangga hanya mamapu memenuhi kebutuhan material saja disebut dengan kelompok kemiskinan spiritual. Keempat, suatu rumah tangga tidak mampu memenuhi kedua kebutuhan tersebut, yaitu kebutuhan material dan spiritual konsidi ini disebut dengen kelompok kemiskinan absolut (Beik dan arsyianti, 2015: 95).

Berdirinya BAZNAS Kabupaten Banyumas secara dasar tidak terlepas adanya perintah melaksanakan zakat dalam Al quran sebagaimana tertulis dalam surat At-Taubah ayat 60 dan 103. Sedangakan secara Yuridis dalam perundang-undangan mengacu pada Surat Keputusan Bupati Banyumas No. 451/1617/03 tanggal 22 November 2003 tentang kewenangan mengelola dana zakat, infaq, shadaqoh, waris, wasiat, hibah, dan karafat dari masyarakat, perorangan pada Dinas Instansi/lembaga. Dengan Adanya UndangUndang Nomor 23 tahun 2011 Tentang Pengelolaan Zakat, serta penegasan Pengelolaan zakat dengan disahkan adanya Surat Keputusan Bupati Nomor 365 Tahun 2013 Tentang Pengurus Badan Amil Zakat Nasional Kabupaten Banyumas Periode 2013-2015. Dengan adanya surat keputusan tersebut BAZNAS menjadi suatu lembaga zakat dalam naungan pemerintahan dan bersifat Nasional yang tersebar diseluruh Indonesia.

LAZISMU Banyumas merupakan jejaring dari LAZISMU PP Muhammdiyah sejak tahun 2002 terkait lembaga nirlaba tingkat kabupaten yang berkidmat dalam upaya mengumpulan dana dana zakat, infak, sodaqoh, dan dana kedermawawan lainnya baik dari pereorangan, lembaga, perusahaan, dan instansi lainnya melalui kegiatan pemberdayaan sejak tahun 2010 yang di tandai dengan 
pengukuhan oleh Ketua pimpinan daerah Muhammdiyah Banyumas. Latar belakang berdirinya LAZISMU Banyumas disebabkan dua hal. Pertama, bermula dari adanya rasa keprihatinan Muhammadiyah atas persoalan kemiskinan dan kebodohan yang terus menyelimuti sebagian masyarakat dan upaya pembangunan manusia yang masih sangat rendah. Kedua, zakat diyakini mampu bersumbangsih dalam mendorong keadilan sosial, pembangunan manusia dan mampu mengentaskan kemiskinan.

Program LAZISMU Kabupaten Banyumas dalam upaya pengelolaan zakat terbagi menjadi bebrapa program fundraising dan program pendayagunaan dana zakat. Diantara programnya adalah pertama; pemberdayaan ekonomi umat meliputi; Ternak Mandiri. Kedua, pengembangan pendidikan meliputi; Anak Asuh lazismu, komunitas PEKKA, senyum anak yatim, UKM berdaya. Ketiga, layanan sosial dakwah meliputi benah rumah SMART, Indonesia siaga, gerakan sodaqoh subuh, Infak 10.000 sandal untuk masjid, sabar berkualitas, kurban enteng, layanan kesehatan. BAZNAS dalam pengumpulan dana berasal dari para Pegawai Negeri Sipil (PNS), namun saat ini berganti istilah dengan Aparatur Sipil Negara (ASN) di lingkungan Kabupaten Banyumas. Pengumpulan tersebut secara otomatis oleh bagian keuangan Unit Pengumpulan Zakat (UPZ) dimasing-masing unit kerja bagi ASN yang beragama islam sebesar $2,5 \%$. Bentuk pemotongan tersebut didasarkan pada surat ketersediaan membayar zakat yang sudah diisi oleh para muzakki dan diserahkan kepada UPZ.

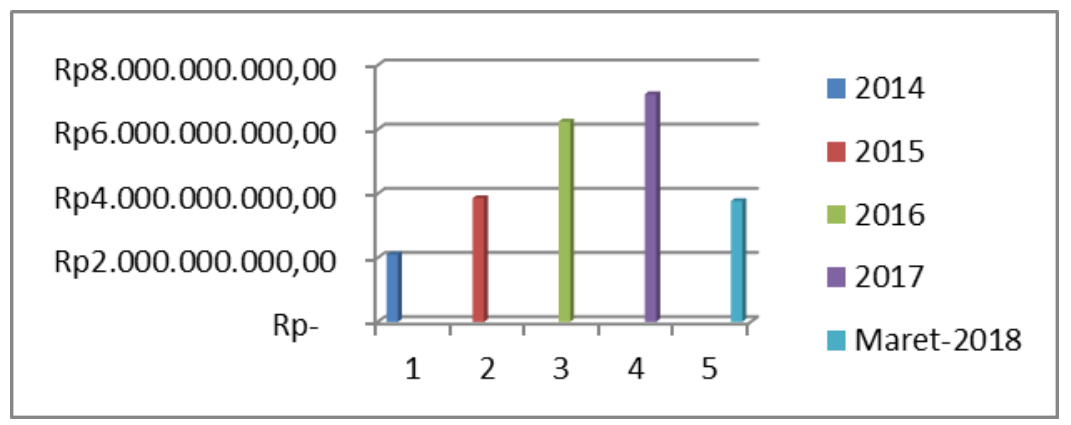

Gambar 1 : Perolehan ZIS BAZNAS 2014-2018 
Sumber : Diolah dari laporan perolehan ZIS BAZNAS 2014-2018

Gambar 1 menunjukan bahwa telah terjadi peningkatan pengumpulan dana yang signifikan semasa rentan waktu 2014-2018. Peningkatakan tersebut dipengaruhi oleh adanya UU No 23 Tahun 2011 tentang pengelolaan zakat, namun juga diikuti dengan penggantian nama BAZDA baik ditingkat Kabupaten/kota menjadi BAZNAS. Dengan berlakunya UU tersebut secara perlahan mengingat ASN ditingkat pusat maupun daerah dalam melakukan pembayaran zakatnya melalui lembaga. Keberadaan BAZNAS yang selama ini memfokuskan diri pengumpulan zakat dari unsur pemerintahan yang baru menyentuh nilai $15 \%$ perlahan mulai ditepis dengan melakukan beberapa upaya inovasi dan evaluasi programnya. Pembinaan UPZ untuk mendorong tersentuhnya para muzakki disegala lini pada saat ini data UPZ per 30 September 2017 mencapai 564 merupakan UPZ tingkat pemerintahan namun yang aktif hanya 227, jumlah UPZ yang bersifat perorangan mencapai 338.

Berdasarkan hasil Rakernas BAZNAS tahun 2017 alokasi penyaluran dalam perhitungan yaitu dana zakat $60 \%$ untuk Fakir miskin, $40 \%$ untuk kebutuhan 7 asnaf lainnnya. Jumlah $60 \%$ alokasi pada fakir miskin terbagi menjadi $20 \%$ pengeluaran konsumtif dan $40 \%$ kegiatan produktif. Pembagian tersebuat tidak dikelola sepenuhnya pada BAZNAS, Dana yang terkumpul setiap periodenya terbagi $60 \%$ di kelola oleh BAZNAS dan $40 \%$ terkelola pada setiap UPZ. Penyaluran dana tersebut mengacu pada prinsip yang tertulis pada surat At-Taubah ayat 60 yaitu mengedepankan keberadaan delapan asnaf dalam penerimaan dana zakat. Penyaluran untuk kebutuhan produktif yang berorientasi pada pemberdayaan persyaratan tambahan yang harus di penuhi selain Surat Tanda Penduduk dan Surat Keterangan Tidak Mampu adalah mengajuan proposal planning bisnis atau bantuan pengembangan usaha yang ditujukan langsung kepada pihak BAZNAS Kabupaten Banyumas yang telah melewati persetujuan dari berbagai pihak salah satunya mengetahui ketua RT atau Dinas yang berkaitan sesuatu prosedural 
yang kemudian pada BAZNAS diadakan rapat khusus, apakah proposal tersebut diterima ataupun tidak. Selain itu, dalam skema program ini juga diadakan pola jemput bola yakni pengelola BAZNAS Kabupaten Banyumas melakukan assessment lapangan mengenai daerah atau lembaga yang berhak menerima program pemberdayaan ini.

Tabel 1 : Syarat pendistribusian ZIS BAZNAS Kabupaten Banyumas

\begin{tabular}{cc}
\hline Konsumtif & Produktif \\
\hline Fakir Miskin, Fisabillah, Ibnu sabil, & Modal usaha (hibah). Modal \\
Ghorim, Muallaf, sarana dan & usaha (pinjaman/dana bergulir) \\
prasaranan kemaslahatan ummat, & modal kelompok usaha kecil, \\
kegiatan ilmiah, benah rumah, & sarana prasarana usaha \\
pendidikan, pengobatan, bencana & \\
\hline
\end{tabular}

Sumber : Wawancara Achmad Musthafa (17/11/2018).

Pengumpulan dana zakat yang dilakukan oleh LAZISMU Kabupaten Banyumas tersebar terhadap berbagai profesi muzakki, sehingga tidak terfokus terhadap donator dari warga muhammadiyah semata. Menurut Direktur LAZISMU Kabupaten Banyumas Sabar Waluyo mengatakan hal tersebut dilakukan untuk menumbuhkan kepercayaan masyarakat bahwa kesadaran dengan keberadaan LAZISMU Kabupaten Banyumas sebagai lembaga penyalur zakat yang bersifat universal, transparansi dan profesional dalam pengelolaanya. Oleh karena itu bentuk dari upaya transparasi pengelolaan dana, adanya laporan dari penyaluran zakat untuk realisasi program yang dilaksanakan. Berbagai upaya yang dilakukan oleh LAZISMU dalam pengumpulan dana zakat berupa spanduk, liflet, direct mail, website dan media sosial.

Tabel 2 : Perolehan ZIS LAZISMU 2018

\begin{tabular}{lll}
\hline No & Nama & Jumlah Perolehan ZIS \\
\hline 1. & LAZISMU Daerah Banyumas & Rp. 3.166 .351 .074 \\
2. & KL Bantarwuni & Rp. 162.210 .000 \\
3. & KL Rawaheng & Rp. 37.671 .564 \\
4. & KL Pasir Wetan & Rp. 21.025 .200 \\
5. & KL Pejagol & Rp. 29.633 .500 \\
\hline
\end{tabular}




\begin{tabular}{lll}
\hline 6. & KL Ajibarang & Rp. 205.948 .750 \\
7. & KL Kalisalak Lumbir & Rp. 101.340 .000 \\
8. & KL Tipar Kidul & Rp. 25.889 .500 \\
9. & KL Baturraden & Rp. 13.103 .000 \\
10. & KL Sidabowa & Rp. 7.300 .000 \\
11. & KL Karanglo & Rp. 81.629 .300 \\
\hline & Total & Rp. 3. 852.101.888 \\
\hline
\end{tabular}

Sumber : Laporan Keuangan LAZISMU tahun 2018

Pengumpulan dana yang dapat dihimpun oleh LAZISMU Kabupaten Banyumas tidak bisa disamakan dengan BAZNAS yang sudah memiliki lahan tetap donator, sehingga setiap tahunnya jumlah pengumpulannya tidak bisa disama ratakan setiap lembaga zakat. Melihat data perolehan diata, LAZISMU Kabupaten Banyumas hanya menerima laporan dari tiap KL (Kantor LAZIS) dari $23 \mathrm{KL}$ pada tahun 2018 hanya 10 yang melaporkan kepada LAZISMU Daerah, namun proses mentasyarufanya dikelola masing-masing KL. Hal ini dilakukan untuk menghindari peecampuran dana dan memudahkan lembaga dalam memetakannya dalam bentuk program yang telah disipakan. Prinsip pentasyarufan pada LAZISMU yaitu dengan sistem alokasi yaitu $60 \%$ untuk pengeluaran produktif dan $40 \%$ untuk pengeluaran konsumtif. Pola penyaluran kepada mustahik tersebut tetap bersandar pada surat At-Taubah ayat 60 . Dalam proses penyaluran dana zakat kepada mustahik ada beberapa hal yang selalu menjadi indikator salah satunya adalah bagaimana mustahik dalam pemenuhan pangan, papan, sandang serta penilai lain dari bagian assessment pentasyarufan. Penyaluran jenis produktif atau sistem pemberdayaan memiliki syarat tambahan yaitu seorang mustahik sudah memiliki program atau usaha yang dijalankan sebelumnya lalu mengajuna proposal pemberdayaan kepada pihak LAZISMU.

Penyaluran zakat produktif yang dilakukan oleh BAZNAS Kabupaten Banyumas. Di bawah ini akan dipaparkan beberapa program yang telah disesuaikan dengan kebutuhan mustahik.

1. Bantuan Ternak program pemberian dana zakat produktigf berupa hewan ternak kepada mustahik yang dikelola secara mandiri, pada 
tahun 2017 bantuna diberikan kepada saudara chotimah di desa Sambeng Kulon kecamatan Kemnaran, namun bantuan ini kurang efektif karena sulitnya dalam melakukan pengawasan pada satu mustahik dalam mengelola hewan ternak.

2. Modal Usaha program pemberian modal usaha sebesar $\mathrm{Rp}$ 500.000-Rp 1.000.000 sebagai usaha dalam mengembangkan usaha. Pengajuan bantuan modal usaha dilakukan secara kolektif oleh masing-masing desa. Tahun 2017 penerima bantuan modal usaha ada 126 orang, dan tahun 2018 ada 32 orang. Salah satu penerimanya yaitu Karsih dan Karisem mustahik desa Tambaksari kecamatan Kembaran menerima bantuan sebesar Rp 500.000

3. Bantuan Sarana Prasarana program pemberian dana pengembangan sarana prasarana usaha dengan kisaran bantuan Rp 2.000.000-Rp 6.000.000. Penerima dana bantuan sarana prasarana tahun 2017 ada 25 mustahik dan tahun 2018 ada 9 mustahik.

4. Usaha Binaan program usaha kelompok berkisar 10 orang dengan memilki usaha dan diberikan dana berkisar Rp 4.000.000-Rp 8.000.000. Salah satu penerimanya adalah PP Bina Rosul.

5. Kantin Sehat pemberian dana zakat produktif untuk pengembangan adanya kantin sehat. Program ini baru berjalan pada tahun 2018. Penerima program ini yaitu UPZ SMP N 1 Jatilawang mendapat bantuan sebesar Rp 8 juta dan MI Maarif NU dan Muhammadiyah yang mendapat bantuan sebesar Rp 6 Juta rupaiah

6. Pelatihan program pelatihan pembuatan telor asin dan desain grafis yang dilakukan di desa Sudagaran Kecamatan Kembaran mendapat bantuan sebesar Rp 2.560.000. Jumlah dana pentasyarufan BAZNAS Kabupaten Banyumas tahun 2017 mencapai Rp 185.173.300 tahun 2018 Rp 81.009.955.

Sedangkan penyaluran zakat produktif yang dilakukan oleh LAZISMU Kabupaten Banyumas meliputi :

1. Pemberdayaan Ekonomi Umat dengan adanya program UKM 
berdaya ini bertujuan untuk membuat UKM berkembang dan juga memperkuat potensi atau daya yang dimiliki dengan cara memberikan bantuan serta pembukuan akses ke dalam berbagai peluang yang akan membuat UKM menjadi makin berdaya. Sasaran dari program ini adalah masyarakat kurang mampu yang memiliki usaha yang sudah berjalan namun belum bisa berkembang secara maksimal. Salah satu penerima dari LAZISMU diberikan kepada Nono Susarno sebesar Rp 3.500.000 seorang pedagang rames di depan Klinik UMP (Universitas Muhammadiyah Purwokerto) selain itu ada juga Uniasih sebesar Rp 350.000 seorang pedagang nasi rames di daerah Pasar Manis. Pada tahun 2018 penerima bantuan UKM berdaya sebanyak 7 orang.

2. Pengembangan Pendidikan program ini merupakan kebijakan strategi untuk memperbaiki kualitas ibadah dan sumber daya manusia melalui pendidikan. Kebijakan strategi ini berfokus pada keberlanjutan pendidikan dan menumbuhkan potensi anak. Jumlah penerima program ini sebanyak 61 orang dan merupakan dari golongan fakir, miskin, sabilillah dan pengawanya dilakukan dengan adanya laporan perkembangan siswa kepada para donator. Jumlah dana untuk pengembangan dana pendidikan ini mencapai Rp 257.939.000. Berdasarkan pentasyarufan LAZISMU Kabupaten Banyumas pada tahun 2018 mencapai Rp 285.097.500.

Berdasarkan proses pentasyarufan (pendistribusian) BAZNAS dan LAZISMU Kabupaten Banyumas dalam mengamati kemiskinan pada masyarakat mengacu pada indikator Surat At-Taubah ayah 60, Badan Pusat Statistik Pada UU No 13 Tahun 2011, serta teori World Bank. BAZNAS dan LAZISMU berfokus pada masyarakat pada kemampuan dasar dalam memenuhi kebutuhan sehari-hari. Namun dalam kaitannya teori yang dikembangakn Irfan Syauqi Beik dan Laily Dwi Arsyianti mengenai empat jenis kuadran kemiskinan dengan teori CIBEST kemiskinan kemiskinan pada Kabupaten Banyumas terletak pada jenis kuadran II yaitu kemiskinan material 
yaitu suatu keadaan masyarakat mampu memenuhi kebutuhan spiritual saja dalam upaya memenuhi kebutuhan material membutuhkan bantuan melalui program dana zakat pada lembaga BAZNAS dan LAZISMU Kabupaten Banyumas

Tabel 3 : Sasaran Penerima Zakat Produktif

\begin{tabular}{|c|c|c|c|c|c|}
\hline No & $\begin{array}{c}\text { Lembaga } \\
\text { Zakat }\end{array}$ & $\begin{array}{l}\text { Program Zakat } \\
\text { Produktif }\end{array}$ & $\begin{array}{l}\text { Sasaran (Sesuai } \\
\text { At-Taubah ayat } \\
60 \text { ) }\end{array}$ & CIBEST & Keterangan \\
\hline 1 & BAZNAS & $\begin{array}{l}\text { a. Modal Usaha } \\
\text { b. Bantuan Sarpras } \\
\text { c. Bantuan Ternak } \\
\text { d. Usaha Binaan } \\
\text { e. Kantin Sehat } \\
\text { f. Pelatihan }\end{array}$ & Miskin & $\begin{array}{l}\text { Kudran II } \\
\text { (Kemiskinan } \\
\text { Material) }\end{array}$ & \multirow{2}{*}{$\begin{array}{l}\text { Upaya mustahik } \\
\text { dalam pemenuhan } \\
\text { kebutuhan } \\
\text { sehari-hari dan } \\
\text { jumlah } \\
\text { pendapatan. Data } \\
\text { BPS daya beli } \\
\text { masyarakat tahun } \\
\text { 2018 yaitu } \\
\text { Rp 300,000 }\end{array}$} \\
\hline 2 & LAZISMU & $\begin{array}{l}\text { a. Pendidikan } \\
\text { b. Pemberdayaan } \\
\text { UKM }\end{array}$ & $\begin{array}{l}\text { Fakir Miskin, } \\
\text { Ibnu Sabil. }\end{array}$ & $\begin{array}{l}\text { Kudran II } \\
\text { (Kemiskinan } \\
\text { Material) }\end{array}$ & \\
\hline
\end{tabular}

Sumber : Diolah dari laporan tahunan BAZNAS dan LAZISMU 2017 pendekatan CIBEST

Menurut Helmut K. Anheier da Diana Leat dalam menganalisisnya pada proses pentasyarufan zakat melalui empat pendekatan. Pertama, pendekatan dengan karitas (charity approach), metode ini lebih bersifat pelayananan sosial sebagaimana yang dilakukan pada abad 19 dan masih dianggap efektif diabad 20, Selain itu metode ini banyak menyorot gejala-gejala ketimbang sebab sumber masalahnya, sehingga metode ini dampak sosialnya tidak begitu terasa. Kedua, filantropi ilmiah (scientific philanthropy), metode ini bertujuan untuk mengurangi atau menghilangkan penyebab kemiskinan dengan cara mengetahui akar penyebab kemiskianan tersebut. Ketiga, neo-filantropi ilmiah (new scientific philanthropy) pendekatan ini kurang memberikan perhatian terhadap nilai-nilai yang unik dalam konteks demokrasi. Keempat, pendekatan kreatif (creative), pendekatan ini dapat mengembangkan berbagai perangkat ketiga pendekatan yang sebelumnya sehingga lebih memiliki dampak yang lebih besar baik secara institusional ataupun pada 
masyarakat (Makhrus, 2018: 32). Pada realisasinya LAZISMU dan BAZNAS menggunakan pendekatan keempat untuk melakukan pengelolaan dana zakat produktif dari beberapa program yang ditawarkan.

Tabel 4 : Peta Pentasyarufan Dana Zakat Produktif

\begin{tabular}{|c|c|c|c|c|c|}
\hline No & $\begin{array}{c}\text { Lembaga } \\
\text { Zakat }\end{array}$ & $\begin{array}{l}\text { Program Zakat } \\
\text { Produktif }\end{array}$ & $\begin{array}{l}\text { Model } \\
\text { Pentasyarufan }\end{array}$ & CIBEST & Keterangan \\
\hline 1 & BAZNAS & $\begin{array}{l}\text { a. Modal Usaha } \\
\text { b. Bantuan } \\
\text { Sarana prasarana } \\
\text { c. BantuanTernak } \\
\text { d. Usaha Binaan } \\
\text { e. Kantin Sehat } \\
\text { f. Pelatihan }\end{array}$ & $\begin{array}{l}\text { Charity, } \\
\text { pemberdayaan }\end{array}$ & $\begin{array}{l}\text { Adanya } \\
\text { pendekatan } \\
\text { spiritual saat } \\
\text { pemberian dana } \\
\text { zakat. Dan } \\
\text { peningkatan } \\
\text { saat adanya } \\
\text { pemberdayaan. }\end{array}$ & \multirow[t]{2}{*}{$\begin{array}{l}\text { Keberlangsu-n } \\
\text { gan dana } \\
\text { selanjutnya } \\
\text { apakah dapat } \\
\text { digunakan } \\
\text { secara } \\
\text { berlanjut atau } \\
\text { sekali habis. }\end{array}$} \\
\hline 2 & LAZISMU & $\begin{array}{l}\text { a. Pendidikan } \\
\text { b. Permberdayaan } \\
\text { UKM }\end{array}$ & $\begin{array}{l}\text { Charity, } \\
\text { pemberdayaan }\end{array}$ & $\begin{array}{l}\text { Adanya } \\
\text { pendekatan } \\
\text { spiritual saat } \\
\text { pemberian dana } \\
\text { zakat. }\end{array}$ & \\
\hline
\end{tabular}

Sumber : Diolah dari laporan tahunan BAZNAS dan LAZISMU 2017 dan pendekatan CIBEST.

Penyaluran dalam bentuk konsumtif pola pemberian dari BAZNAS adalah dengan sifat charity yaitu pemberian dana untuk kebutuhan pengentasan kemiskinan dari mustahik yang langsung dapat digunakan saat itu juga. Berbeda dengan penyaluran dana produktif yaitu mengedepankan sifat pemberdayaan dimana pihak BAZNAS menjadikan penyaluran tersebut menjadi dua sistem yaitu penyaluran dana produktif dalam pola pemberian modal usaha setelah dilakukan proses pelatihan atau pemberian pengadaan atas usaha yang ada. Dengan teori CIBEST proses Charity berfokus pada bagaimana nantinya dana tersebut digunakan untuk meningkatkan kemampuan mustahik dalam hal materialnya, sedangkan proses pemberdayaan pentasyarufan dapat diimbangi dengan memberikan stimulan kepada mustahik dalam spiritual dan penyadaran. seorang mustahik yang berada pada jenis kuadran II menurut teori CIBEST atau masuk dalam kategori miskin dengan adanya program 


\section{pemberdayaan dari zakat produktif ini diharapkan adanya perubahan serta meningkat menjadi seorang muzzaki.}

Tabel 5 : Evaluasi program zakat produktif dengan pendekatan teori CIBEST

\begin{tabular}{|c|c|c|c|c|}
\hline No & $\begin{array}{c}\text { Lembaga } \\
\text { Zakat }\end{array}$ & $\begin{array}{c}\text { Program Zakat } \\
\text { produktif }\end{array}$ & Realisasi & CIBEST \\
\hline \multirow[t]{6}{*}{1} & BAZNAS & Modal Usaha & $\begin{array}{l}\text { Tahun } 2017: 126 \\
\text { Tahun } 2018: 32\end{array}$ & $\begin{array}{l}\text { Spiritual meningkat dengan } \\
\text { adanya pengajian setiap hari } \\
\text { kamis. Material meningkat } \\
\text { dari sebelumnya. }\end{array}$ \\
\hline & & Bantuan Sarpras & $\begin{array}{l}\text { Tahun } 2017: 25 \\
\text { Tahun } 2018: 9\end{array}$ & $\begin{array}{l}\text { Indikator Spiritual } \\
\text { meningkat ditandai dengan } \\
\text { adanya kajian bersama } \\
\text { penerima zakat produktif. }\end{array}$ \\
\hline & & Bantuan Ternak & $\begin{array}{l}\text { Tahun } 2017: 1 \\
\text { Tahun } 2018: 1\end{array}$ & $\begin{array}{l}\text { Tidak efektif karena berlaku } \\
\text { pada satu orang. } \\
\text { Peningkatan hanya pada } \\
\text { spiritual. }\end{array}$ \\
\hline & & Usaha Binaan & $\begin{array}{l}\text { Tahun } 2017: 1 \\
\text { Tahun } 2018: 7\end{array}$ & $\begin{array}{l}\text { Indikator spiritual } \\
\text { meningkat dengan ditandai } \\
\text { adanya infak setiap bulan } \\
\text { yang dilakukan } \\
\text { berkelompok. }\end{array}$ \\
\hline & & Kantin Sehat & $\begin{array}{l}\text { Tahun } 2017: 5 \\
\text { Tahun } 2018: 10\end{array}$ & $\begin{array}{l}\text { Indikator spiritual } \\
\text { meningkat dengan adanya } \\
\text { program infak yang } \\
\text { diserahkan kepada BAZNAS }\end{array}$ \\
\hline & & Pelatihan & $\begin{array}{l}\text { Tahun } 2017: 11 \\
\text { Tahun } 2018: 2\end{array}$ & $\begin{array}{l}\text { Indikator spiritual } \\
\text { meningkat dengan adanya } \\
\text { program kajian bersama dan } \\
\text { tinjauan dari takmir. } \\
\text { Indikator material meningkat } \\
\text { dengan adanya pendapatan. }\end{array}$ \\
\hline \multirow[t]{2}{*}{2} & LAZISMU & Pendidikan & $\begin{array}{l}\text { Tahun } 2016: 36 \\
\text { Tahun } 2017: 61\end{array}$ & $\begin{array}{l}\text { Indikator spiritual } \\
\text { meningkat dengan adanya } \\
\text { program pengawasan dari } \\
\text { sekolah atau pendidikan. } \\
\text { Material keluarga meningkat } \\
\text { untuk kebutuhan sehari-hari. }\end{array}$ \\
\hline & & $\begin{array}{l}\text { Pemberdayaan } \\
\text { UKM }\end{array}$ & 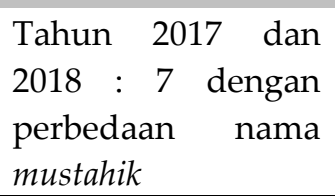 & $\begin{array}{l}\text { Indikator spiritual } \\
\text { meningkat dengan adanya } \\
\text { pengawasan dari takmir dan } \\
\text { PCM Muhammadiyah. }\end{array}$ \\
\hline
\end{tabular}


Indikator meningkat dengan kenaikan pendapatan.

Sumber: Diolah dari laporan tahunan BAZNAS dan LAZISMU 2017-2018

Tabel 4.5 menjelaskan perubahan yang signifikan dengan adanya perubahan jumlah angka dari tahun sebelumnya. Pada tahun 2017 pengentasan kemiskinan yang berhasil dilakukan oleh BAZNAS ada 930 orang dari jumlah mustahik yang terdata, tahun 2018 berhasil mengentaskan 26 orang. Sedangkan pada LAZISMU belum dilakukan data secara detail. Namun adanya perubahan jumlah angka tersebut dipengaruhi oleh beberapa faktor yaitu: pertama, jumlah mustahik tahun 2018 menurun dari tahun sebelumnya dikarenakan bukan terjadi penurunan namun suatu data baru penerima dana zakat pada periode tersebut dan mereka tidak mengajukan lagi pada tahun berikutnya.

Kedua, adanya perubahan program kegiatan yang sebelumnya dilakukan pada tahun 2017 tidak dilakukan lagi pada tahun selanjutnya karena adanya pertimbangan dan merupakan suatu usulan program baru yang diusulkan saat rapat evaluasi lembaga. Dengan teori CIBEST seorang mustahik yang menerima zakat produktif ditahun 2017 maupun 2018 mengalami perubahan yaitu perubahan pada segi spiritual dan material. Perubahan spiritual ini terjadi saat seorang mustahik mendapatkan dana zakat produktif dan saat pengawasan dan perubahan material terjadi adanya perubahan jumlah pendapatan yang didapatkan dari usahanya sebelum dan sesudah adanya zakat produktif.

Sehingga dapat disimpulkan bahwa program-program lembaga dalam pengentasan kemiskinan mengalami perubahan namun belum sepenuhnya efektif. Pengawasan dilakukan untuk mengevalusi apakah dana produktif tersebut digunakan seefektif mungkin. Kurangnya sumber daya manusia pada lembaga zakat sebagai para pendamping program pemberdayaan. Pengawasan yang dilakukan oleh BAZNAS dan LAZISMU dilakukan saat proses pemberian dana pada mustahik dan pengajuan ulang. Hal ini dikarenakan jumlah 
Sumber Daya Insani pada lembaga zakat yang tidak memadai. Kedua lembaga tersebut perlu melakukan kerjasama dengan pihak lain yang memiliki konsentrasi program yang sama. Sehingga harapanya hambatan yang telah diuraikan tadi menjadi sebuah evalusi untuk kedua lembaga dalam mengoptimalkan dan memaksimalkan dana zakat dalam upaya pengentasan kemiskinan melalui program pemberdayaan agar tercipta mustahik yang berdaya dan mampu mengentasakan kemiskinan secara mandiri.

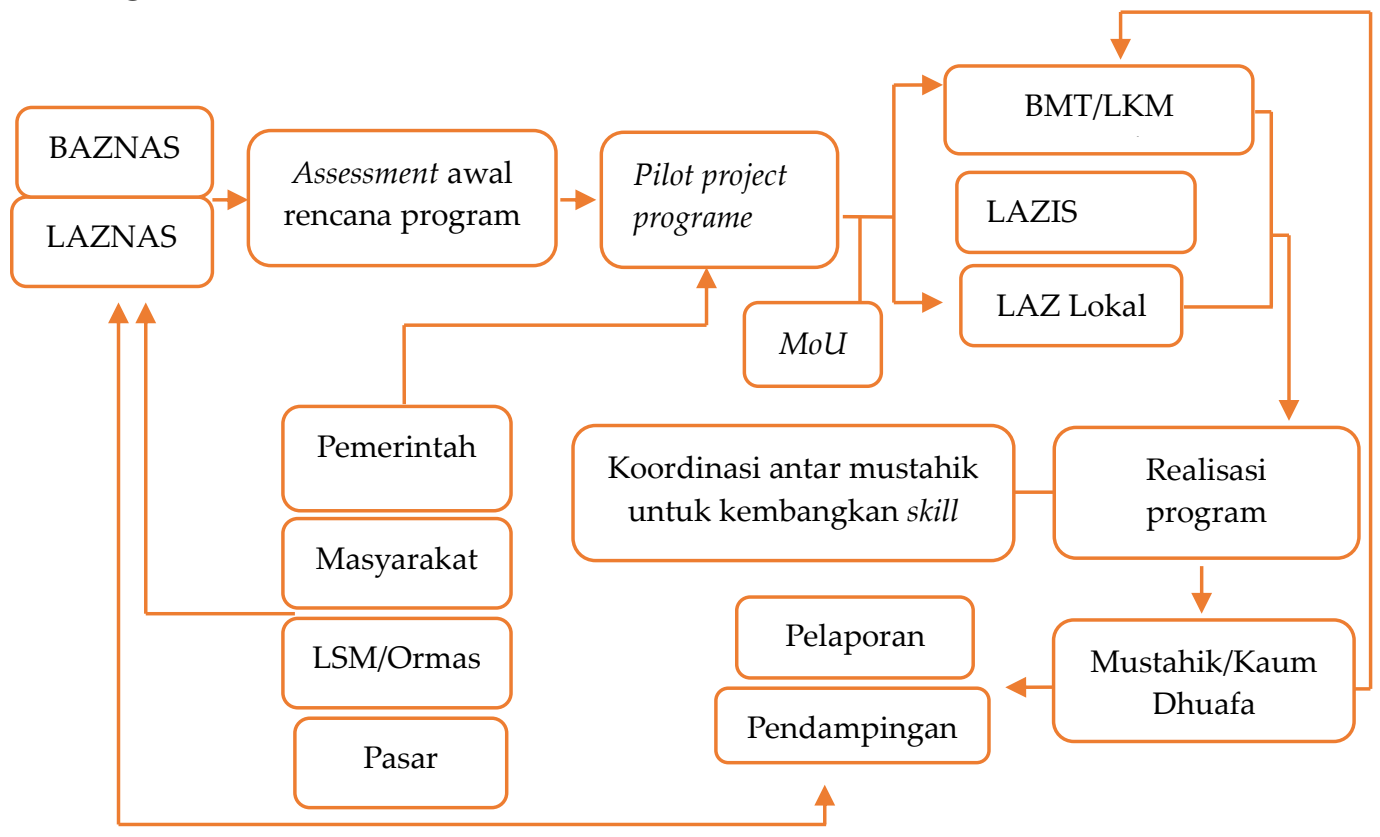

Gambar 2 : Proses Sindikasi Program BAZNAS dan LAZ Sumber : Makhrus, 2018: 97

Gambar 2 menunjukan suatu sindikasi manajemen BAZNAS dan LAZISMU yang seharusnya. Pada hasil penelitian dijelaskan bahwa BAZNAS Kabupaten Banyumas dalam membuat program pengelolaan zakat produktif berdasarkan pada pengajuan proposal mandiri dari mustahik yang nantinya akan dirapatkan bersama saat rapat internal BAZNAS apakah program dari proposal tersebut dapat dijalankan. Dengan demikian program zakat produktif pada BAZNAS hanya mengacu pada program mandiri dan kebutuhan dari mustahik. Untuk itu BAZNAS memerlukan inovasi program baru yang lebih mengutamakan kegiatan pemberdayaan, kemudian 
disosialisasikan kepada mustahik, sehingga selain BAZNAS menunggu proposal pengajuan mandiri dari mustahik.

BAZNAS juga memiliki program unggulan yang dapat diterapkan untuk mustahik. Proses pengajuan proposal mandiripun melalui beberapa tahapan yang harus dilalui oleh mustahik secara sistematis karena pola pemberdayaan masyarakat yang dilakukan BAZNAS ingin melibatkan beberapa unsur yakni: lembaga pendidikan, pengelola usaha, aparat pemerintah setempat dan masyarakat namun dengan hal ini justru memuat pengajuan proposal menjadi kaku dan berdampak pada waktu yang harus dikeluarkan demi sebuah proses tahapan prosedur dan tidak semua mustahik memahami tentang teknis prosedur yang harus dipersiapakn sebagai prasyarat pengajuan pemberdayaan masyarakat kepada BAZNAS.

Berbeda dengan LAZISMU Kabupaten Banyumas pola pengelolaan zakat produktif yang dilakukan tidak terlalu birokrasi sebagaimana yang dilakukan oleh BAZNAS Kabupaten Banyumas. Pola pengelolaan dilakukan secara button up dan memperluas dalam proses funding dana zakat. Dimana penguatan terhadap assessment dilakukan sedetail mungkin selain itu dalam proses funding LAZISMU dengan latarbelakang sebagai lembaga dalam naungan Muhammdiyah dapat memperluas sosialisasi atau marketingnya pada sektor amal usaha Muhammadiyah dan warga Muhammdiyah seperti yang dilakukan oleh BAZNAS pada pegawai ASN. Meskipun LAZISMU berorentasi pada semua masyakat tidak terkecuali masyarakat muhammadiyah. Dalam pengembangnya LAZISMU dengan tidak terikat oleh lembaga manapun seharusnya dapat mengoptimalkan pada potensi masyarakat melalui teknik analisis yang detail serta perlu melakukan adanya proses pelatihan yang dapat diberikan oleh pihak-pihak lembaga lain yang berada dalam naungan muhammadiyah seperti adanya MDMC, lembaga pendidikan muhammadiyah, lembaga potensi masjid. Meskipun programnya satu namun bentuk pelaporannya dilakukan tersendiri kepada masingh-masing lembaga yang bersangkutan. 
Berdasarkan adanya sindikasi program ini, barangkali tidak bisa terjadi dalam banyak program, melainkan cukup untuk program pemberdayaan masyarakat tertentu yang memungkinkan kedua lembaga bisa optimal dalam menjalankan perannya dalam upaya pengentasan kemiskinan di Kabupaten Banyumas. Melalui lembaga yang ditunjuk sebagai basis komunikasi atau sebuah forum bersama. Keberadaan forum ini akan memudahkan dalam upaya pendampingan sebab dari forum bersama semua hal akan dibahas secara lebih matang oleh internal forum.

\section{DAFTAR RUJUKAN}

Al-Zuhayly, Wahbah. 2005. Zakat (Kajian Berbagai Mazhab), diterjemahkan oleh Agus Effendi dan Bahruddin Fananny dari Buku Asli "Al-Fiqh Al-Islami Adilatuh", Bandung: PT. Remaja Rosdakarya.

Abdullah, Boedi dan Beni Ahmad Saebeni. Metode Penelitian Ekonomi Islam. Bandung: CV Pustaka Grafika.

Beik, Irfan Syauqi, and Laily Dwi Arsyianti. 2015. Construction of CIBEST

Model as Measurement of Poverty and Welfare indices FromIslamic Perspective. Al-Iqtishad: Jurnal Ilmu Ekonomi Syariah, 7(1), 87-104.

Efendi, Mansur.2017. Pengelolaan Zakat Produktif Berwawasan

Kewirausahaan Sosial dalam Pengentasan Kemiskinan di

Indonesia. Al-Ahkam: Jurnal Ilmu Syariah dan Hukum, 2(1).

Fadilah, Arief, and Ating Sukma. 2016. Efektifitas Program Pendistribusian

Dana Zakat di Badan Amil Zakat Nasional (Baznas) Kota Bogor. Jurnal Syarikah: Jurnal Ekonomi Islam, 2(2).

Herdiansyah, Haris, 2011. Metodologi Penelitian Kualotatif Untuk Ilmu-Ilmu Sosial. Salemba Humanika: Jakarta Selatan.

Makhrus, dan Restu Frida Utami "Peran Filantropi Islam dalam Pemberdayaan Masyarakat di Kabupaten Banyumas" Seminar LPPM UMP 2015, Purwokerto; Universitas Muhammadiyah Purwokerto.

Makhrus. 2018. Dinamika dan Aktivisme Filantropi Islam dalam Pemberdayaan Masyarakat. Litera: Yogyakarta

Makhrus, M. "Pengelolaan Zakat Produktif dalam Upaya Pengentasan

Kemiskinan di Indonesia." JURNAL HUKUM EKONOMI SYARIAH 2.1 (2019): 37-50.

Manullang, M., 1985.Dasar-Dasar Manajemen. Cetakan Kesebelas. Penerbit 
Ghalia Indonesia. Jakarta.

Muhammad, 2004. Manajemen Bank Syariah, Edisi Revisi.Yogyakarta: UPP AMP YKPN

Mujahidin, 2016. Hukum Perbankan Syariah, Jakarta: PT Rajagrafindo Persada.

Mulyawan, Dadang dkk 2016. Pengelolaan Zakat yang Efektif: Konsep dan Praktik diberbagai Negara, Jakarta: Depatemen Ekonomi dan Keuangan Syariah Bank Indonesia.

Nasrullah, Nasrullah.2015. Regulasi Zakat dan Penerapan Zakat Produktif sebagai Penunjang Pemberdayaan Masyarakat (Studi Kasus Pada Baitul Mal Kabupaten Aceh Utara). Inferensi Jurnal Penelitian Sosial Keagamaan, 9(1), 1-24.

Pratama, Yoghi Citra.2015. Peran Zakat dalam Penanggulangan Kemiskinan (Studi Kasus: Program Zakat Produktif pada Badan Amil Zakat Nasional). Tauhidinomics, 1(1), 93-104.

Pahril, Husaeni and Wage, Wage, 2018 "Peran LAZISMU BANYUMAS dalam Pemeberdayaan Ekonomi Masyarakat. Prosiding Seminar Nasional Prodi Hukum Ekonomi Syariah. http://digital.library.ump. ac.id/22/

Saifulloh, Nur Imam. 2018. Analisis Tingkat Kemiskinan Kaum Urban Berdasarkan Indeks Cibest di Kecamatan Kepil Kabupaten Wonosobo. IQTISHADIA: Jurnal Ekonomi\&Perbankan Syariah, 5(1), 22-42.

Sudarsono, H., 2003. Bank \& Lembaga Keuangan Syariah: Deskripsi dan Ilustrasi. Ekonisia.

Syamsuri, Syamsuri.2016. Paradigma Pembangunan Ekonomi; Satu Analisis Tinjauan Ulang dari Perspektif Ekonomi Islam. Islamiconomic: Jurnal Ekonomi Islam, 7(2).

Triyawan, Andi.2017. Analisis Faktor-Faktor yang Mempengaruhi Muzakki Membayar Zakat di BAZNAS Yogyakarta. Islamic Economics Journal, 2(1).

Wardhani, Rama Wijaya Kesuma. 2018. Manajemen Komunikasi Badan Amil Zakat Nasional (BAZNAS) Provinsi Jawa Barat. NALAR: Jurnal Peradaban dan Pemikiran Islam, 2(1), 12-21.

Widiastuti, Tika, and Suherman Rosyidi. 2015. Model Pendayagunaan Zakat Produktifitas oleh Lembaga Zakat dalam Meningkatkan Pendapatan Mustahiq. Jurnal Ekonomi dan Bisnis Islam (JEBIS), 1(1), 
Pengelolaan Zakat Produktif dalam Pengentasan Kemiskinan ......... Septi Wahyuningsih, Makhrus

89-101.

Widyani, Hani. 2014. Analisis Penanggulangan Kemiskinan Melalui Implementasi Program Dana Bergulir Badan Amil Zakat Kota Bandung. Afkaruna: Indonesian Interdisciplinary Journal of Islamic Studies, 10(2), 180-201.

Wulansari, Sintha Dwi, and Achma Hendra Setiawan. 2014. Analisis Peranan Dana Zakat Produktif Terhadap Perkembangan Usaha Mikro Mustahik (Penerima Zakat) (Studi Kasus Rumah Zakat Kota Semarang). Diponegoro Journal of Economics, 3(1), 26-40

Undang-Undang Zakat No.23 Tahun 2011 